\title{
An exploratory study of visually impaired students' perceptions of inclusive mathematics education
}

British Journal of Visual Impairment 2015, Vol. 33(3) 212-219 (c) The Author(s) 2015 Reprints and permissions: sagepub.co.uk/journalsPermissions.nav DOI: $10.1177 / 0264619615591865$ jvi.sagepub.com

\author{
Gözde İrem Bayram \\ TED Bursa College, Turkey
}

\section{Sencer Corlu}

Bilkent University, Turkey

\section{Emin Aydın}

Marmara University, Turkey

\section{Deniz Ortaçtepe}

Bilkent University, Turkey

\section{Burcu Alapala}

Eyuboglu Educational Institutions \& Boğaziçi University, Turkey

\begin{abstract}
The Turkish Disability Act introduced inclusive education to Turkey as a solution to the problems experienced by students with disabilities, including visually impaired students. The main purpose of this study was to explore the challenges faced by visually impaired students learning high school mathematics in inclusive classrooms in Turkey. The data were qualitative, consisting of interviews conducted with three high school graduates; they were analysed using the constant comparison method. In the interviews, students described the effects of various teaching methods on their learning and evaluated the social aspect (broadly speaking) of inclusive education. The results show that while the social needs of visually impaired Turkish students were adequately met through inclusive education, their academic needs were not, which we speculate to be partly because of mathematics teachers' negative attitudes towards inclusive education.
\end{abstract}

\section{Keywords}

Education in Turkey, inclusive education, mathematics education, social aspect of learning, visually impaired students 


\section{Introduction}

The six principles of mathematics education were introduced in the United States to guide teachers in their classroom practice; however, they have also had broad impact in other countries, including Turkey (the context of the present study; cf. Turkish Ministry of National Education [MoNE], 2013). They are equity, curriculum, teaching, learning, assessment, and technology (National Council of Teachers of Mathematics [NCTM], 2000). The principles are interdependent; however, the principle of equity is at the core of all the others. Equity in the mathematics classroom means addressing student needs by creating a fair class environment in which all students have an equal opportunity to fulfil their potential (Bartell \& Meyer, 2008). Equity requires effective teaching, so that the gap among students with different needs and degrees of need can be narrowed while they learn mathematics in a productive environment (Allexsaht-Snider \& Hart, 2001).

Research has suggested that the efforts of students with disabilities are not enough on their own to close the gap between them and other students when the classroom environment is not conducive to learning for these students and/or their teachers are not effective (Zhou, Parker, Smith, \& Griffin-Shirley, 2011). Visually impaired students need motivated teachers who can address their learning styles (Anthony \& Walshaw, 2009; Figueiras \& Arcavi, 2014; Quek \& McNeill, 2006). The equity principle requires the collaboration of all members of a classroom, including both visually impaired and sighted students and their teachers.

\section{The current situation in Turkey}

Alongside the passing of the Turkish Disability Act in 2005, MoNE (2006) renewed its Education Regulations for Disabled Students document and introduced inclusive education as a solution to the problems experienced by students with disabilities. The rationale behind the new regulations was the belief that inclusive education would solve both social and academic problems in the classroom for students whose disabilities were not severe (Erol, 2010; Varol, 2010). MoNE suggested that in inclusive education practice, all members of the school community, including not only visually impaired students but also teachers and sighted students, be involved in inclusive education (i.e. that disabled and non-disabled students be involved in each other's education process; MoNE, 2006). The hope was that inclusive education would create an academically and socially ideal and affordable educational environment for students with disabilities, including visually impaired students (Wang, 2009).

\section{Special needs training of mathematics teachers}

In the limited literature on Turkish mathematics teachers, it has been found that they have not received (pre-service or in-service) education in teaching disabled students; therefore, their knowledge of the exact nature of the special needs of visually impaired students is limited, and they do not know how to address the specific needs of their students (Köseler, 2012). In a study on reading graphs, the researcher suggested teachers build up their confidence and construct their own handson teaching materials for their visually impaired students (Bülbül, 2013). In fact, Needle Page - a book including teacher-designed materials - is an example of such materials written in Turkish, which can be used for teaching middle school algebra and statistics (Bülbül, Cansu Kurt, Garip, Demirtaş, \& Eryurt, 2013).

Mathematics teachers in other countries also experience some problems teaching students with disabilities (Akakandelwa \& Munsanje, 2012; Healy \& Fernandes, 2011; Pritchard \& Lamb, 2012). For instance, studies have shown that American teachers in general do not know how to access or use assistive technology in their lessons. However, effective mathematics teachers were found to 
be skilled in using assistive technology, such as computer programs with screen readers, closedcircuit television (CCTV), or Nemeth-Braille devices (Freeland, Emerson, Curtis, \& Fogarty, 2010). Another study showed that teachers with these skills were able to facilitate a motivating classroom environment where their teaching was relevant to visually impaired students (Freire, Linhalis, Bianchini, Fortes, \& Pimentel, 2010; Zhou et al., 2011).

\section{Research question}

This exploratory study has collected the first data related to a larger research project initiated by a team of teachers and teacher educators who believe that our knowledge base on the education of visually impaired students in Turkey is unacceptably scarce and inadequate to be of use in addressing the need to help policymakers give informed decisions. The main purpose of this first study was to explore the challenges faced by visually impaired students. Specifically, we wondered what some of their major challenges in mathematics were and how we could describe those challenges with respect to inclusive classroom context in Turkey.

\section{Methods}

The participants in this qualitative study were chosen purposefully in order to secure informationrich cases (Lincoln \& Guba, 1985). The sample was a group of visually impaired students who had experienced inclusive high school education. Brief profiles of the students are presented as part of the findings below. Pseudonyms are used. Data consisted of transcripts of interviews conducted in the native language of the participants (Turkish). Interview data were supported by field notes and observations made by the researchers during our tutoring of one of the participants, and those helped us triangulate the data acquired from the interviews. Data were analysed using the constant comparison method, which involves unitising and categorising the data, recognising the patterns, collecting similar categories together and finally identifying critical themes as they emerged inductively from similar categories after grouping.

\section{Key findings}

\section{Profiles}

Cem (I 8 years old). Cem has been in inclusive education for his entire school life. In 11 th grade, he went to the United States as an exchange student. He compared inclusive education in the United States to that in Turkey and said practices in both countries shared common problems with respect to teacher competence in and interest towards teaching visually impaired students. However, he indicated that he enjoyed the variety of the resources available to him in the United States.

Umut (20 years old). During both elementary and middle school, Umut attended schools that specialised in educating visually impaired students. However, he transferred to a regular high school, where he continued his education in inclusive classrooms, together with sighted students. There was only one other visually impaired student at his school, and Umut was the only one in his class. After doing 3 months of tutoring on mathematics with him, we were glad to see that Umut was accepted to the university he wanted to attend.

Rabia (24 years old). Rabia gave the impression of being a young, independent woman. She said, 'I can handle everything; this sight is enough for me', referring to her very limited sight ( $5 \%$ of full visual 
capacity). Rabia had attended neither an elementary nor a middle school; instead, she had been party to an arrangement with the Ministry of National Education in which she could continue high school if she could pass the entrance examinations. She did so after a 2-month-long preparation period.

\section{Informants' perspectives about their teachers' attitudes}

Informants described the effects of different teaching methods on their learning; they also shared their experiences in the mathematics classroom and evaluated several teaching methods. Rabia brought up the matter of teacher prejudice by giving an example:

I need to deal with serious problems in [learning] mathematics ... one of my teachers said that visually impaired students cannot learn mathematics. I do not agree. I can learn mathematics . . Not all visually impaired students are similar to each other.

Rabia had believed in her ability to learn mathematics; however, the attitude of one of her mathematics teacher ruined this belief. She explained that several of her teachers tried to ignore her and did not care about her success. In general, Rabia felt that teachers really did not want to take on the responsibility of teaching visually impaired students and were afraid to update their knowledge and move with the times:

Teachers are trying to get rid of us. They always complain about not having the skills. There were seminars about inclusive education or it is written in the regulation book ... [T] hey could share their experiences and talk about what could be done for us, but they do not prefer to discuss it. They [except two or three] do not want to learn about it or change their methods. This creates prejudice on both sides.

Cem stated that teachers did not have enough information about visually impaired learning materials and were not interested in learning about them. He explained,

They have some prejudices about how to give inclusive education in math lessons and how to deal with [the problems of] visually impaired students.

In the experience of the informants, teachers did not know about the Braille alphabet, were not informed about the challenges of taking notes with Braille, or how to use materials for teaching visually impaired students. Therefore, these students had found that their teachers had little effect on their learning. Cem explained,

Mathematics teachers do not know about the special abacus [available] for us, the Braille alphabet, or how to use these effectively [in mathematics lessons]. They do not help us in terms of material use or ask to learn about the materials.

There were vast differences between the learning styles of these visually impaired students and the teaching methods they had experienced in their mathematics classes. Umut said that inappropriate teaching methods were always the most important problem for him, and that some of his teachers tried to implement effective teaching methods at first, but gave up after a while:

At first my teachers tried to explain everything to me after [explaining it for] the [crowded] class [on the white board]. However, since it was time consuming and caused some problems [among the sighted students], they advised me to study with my classmates and take notes from them. But that did not work very well for me. 
Rabia explained that despite these teaching problems, one of her teachers did find a teaching method that was beneficial for her. However, this method also had a drawback for both visually impaired and sighted students:

One of my mathematics teachers was teaching very fast. She was teaching the content very quickly to whole class so that she could save time for summarising the lesson for me. The sighted students could not understand what she was teaching because she was too fast for them. But I could understand the content. She was explaining to me according to my learning style.

The other students in the class started to complain because the teacher was rushing through the topic in order to make some time for Rabia. Because this was not convenient for all the students in the classroom, instead of trying to adjust her method, the teacher simply gave up this method after a while, like Umut's teacher.

\section{Materials use in mathematics learning}

Effective materials use is important to further the mathematical achievement of visually impaired students, especially when they are not benefitting from their teaching at school. They can use various materials to have a deeper understanding of mathematics, but the point these materials have in common is that they allow the student to learn through assessment of their own understanding and seeking immediate support when they need to. The most useful materials for visually impaired students are those with no (or little) visual component or with voice support. The present participants preferred different types of materials according to their individual needs and the functionality of the materials. During the interviews, they were quite explicit in expressing the advantages and disadvantages of these materials, including writing in the Braille alphabet, using Job Access With Speech (JAWS) screen reading software, and reading Braille textbooks.

The first material that was commonly used was Braille and support systems. Mathematical content can be a difficult matter when writing in Braille, since writing in Braille is a linear process: students need to write everything in linear form before checking whether it is correct or not. There are some modifications to Braille for mathematical representation, namely, the Nemeth codes, but the present participants did not know about them (meaning that they had not encountered them in their mathematics lessons).

However, some of them came up with similar solutions on their own. Cem said that Braille was beneficial for him but became even more beneficial after he made some modifications to it:

I still did not come across the mathematical notation. In Braille I did not learn them [because of a time problem]; hence I made up my own notation. It got more complicated with more notations, but I got used to it.

The second material used by all participants was software called JAWS. Cem said that they were using JAWS to read online documents. However, there existed some problems with it: Cem said that the software interpreted some mathematical notations as images, especially things like integrals or matrices, and leaves those parts as a space while reading:

It reads everything but only if it is in text format. It was not designed for mathematics . . . It does not read dots in the text. It reads 3.5 as three dot five not as multiplication. Therefore, it is not useful in mathematics. It confuses me.

The third material was the mathematics textbooks translated into the Braille alphabet and given to the visually impaired students by MoNE for free. However, none of the participants benefitted 
much from these books: Rabia said that it was not beneficial for her since there were too many errors and missing elements when compared to the original textbook. Specifically, the examples, connections, graphics, pictures, and charts were excluded in the Braille translated version.

\section{The social aspect of inclusive education}

The aim of education is not just ensuring academic success at school but also preparing students for their future lives. For visually impaired students, there are many obstacles to doing so. Inclusive education benefits not only visually impaired students but also sighted students, in terms of academic success, social sensitivity, and social awareness. These social elements constitute an aspect of inclusive education just as important as academic learning, for both sighted and visually impaired students.

Cem agreed that inclusive education had effects on both visually impaired students and sighted students. He reported that his friends came to appreciate the catalyser effect the visually impaired students had on their academic success and social awareness in the classroom. This effect emerged because, as Cem highlighted, inclusive education led their friends to become more sensitive to the problems which the visually impaired students were trying to handle. Several sighted students became more successful because they were studying together with one of the visually impaired students; Cem noted,

My friends told me that since I was abroad in the USA last year, their mathematics grades decreased. The only reason for this is because we were always studying together, benefitting both sides.

Rabia said that she benefitted from inclusive education a lot, too. She had different types of friends, but they all supported her and helped her learn more. She elaborated,

Even though we are doing inclusive education, we experience many communication problems; however, we also learn how to tolerate and persevere through those problems. Therefore, inclusive education is important, at least, for our personality development [as well as communication development].

\section{Conclusion}

Inclusive education has been said to provide both visually impaired and sighted students with various opportunities to increase their academic achievement and social awareness (MoNE, 2006). Although the present research shows that the social needs of visually impaired students can be met through inclusive education, it also shows that their academic needs were not met, partly because of teachers' negative attitudes towards inclusive education and particularly towards teaching visually impaired students (cf. Demir \& Açar, 2011). For the provision of the best inclusive education in terms of addressing both academic and social needs, teachers have a critical responsibility. Teachers' negative attitudes may result from a lack of interest about what visually impaired students experience in the classroom (Spindler, 2006) or a lack of knowledge about mathematics teaching or about the use of materials developed for visually impaired students (Rosenblum \& Herzberg, 2011).

Looking back on this research, we believe that teachers' interest in and knowledge about teaching visually impaired students can be increased by implementing need-specific professional development activities or by creating opportunities for interaction between experienced special education teachers and mathematics teachers. Our final words are from Francis Fennell (2007), past president of NCTM (2006-2008), who suggested that special education and mathematics teachers work in 
collaboration. The next stage of our project will build on our initial experience and investigate how mathematics and special education teachers collaborate in their efforts to teach advanced levels of mathematics to visually impaired students within inclusive education.

\section{Declaration of conflicting interests}

The authors declared no potential conflicts of interest with respect to the research, authorship, and/or publication of this article.

\section{Funding}

The authors received no financial support for the research, authorship, and/or publication of this article.

\section{References}

Akakandelwa, A., \& Munsanje, J. (2012). Provision of learning and teaching materials for pupils with visual impairment: Results from a national survey in Zambia. British Journal of Visual Impairment, 30, 42-49.

Allexsaht-Snider, M., \& Hart, L. E. (2001). 'Mathematics for all': How do we get there? Theory into Practice, 40, 93-101.

Anthony, G., \& Walshaw, M. (2009). Effective pedagogy in mathematics (Vol. 19). Geneva, Switzerland: International Bureau of Education.

Bartell, T. G., \& Meyer, M. Y. (2008). Addressing the equity principle in the mathematics classroom. Mathematics Teacher, 101, 604-608.

Bülbül, M. Ş. (2013). Görme engelli öğrenciler ile grafik çalışırken nasıl bir materyal kullanılmalıdır? [What sort of materials should be used while studying graphs with visually impaired students?]. Fen Eğitimi ve Araştırmaları Derneği Fen Bilimleri Öğretimi Dergisi, 1(1), 1-11.

Bülbül, M. Ş., Cansu Kurt, Ü., Garip, B., Demirtaş, D., \& Eryurt, K. (2013). Herkes için basit malzemelerle matematik: İgneli sayfa cebir uygulamaları [Mathematics for everyone with simple materials: Algebra applications with Needle page]. Ankara, Turkey: Pegem Akademi.

Demir, M. K., \& Açar, S. (2011). Kaynaştırma eğitimi hakkında tecrübeli sınıf öğretmenlerinin görüşleri [Opinions of experienced classroom teachers about inclusive education]. Kastamonu Eğitim Dergisi, $19,719-732$.

Erol, F. (2010). Özel eğitim okullarında özel eğitim hizmetleri uygulamalarının değerlendirilmesi [An evaluation of the special education practices]. Ankara, Turkey: Ministry of National Education.

Fennell, F. (2007). What's so special about special education? Everything! NCTM News Bulletin, 44(3), 3.

Figueiras, L., \& Arcavi, A. (2014). A touch of mathematics: Coming to our senses by observing the visually impaired. ZDM: The International Journal on Mathematics Education, 46, 123-133.

Freeland, A. L., Emerson, R. W., Curtis, A. B., \& Fogarty, K. (2010). Exploring the relationship between access technology and standardized test scores for youths with visual impairments: Secondary analysis of the national longitudinal transition study. Journal of Visual Impairment \& Blindness, 104, $170-182$.

Freire, A. P., Linhalis, F., Bianchini, S. L., Fortes, R. P., \& Pimentel, M. D. G. C. (2010). Revealing the whiteboard to blind students: An inclusive approach to provide mediation in synchronous e-learning activities. Computers \& Education, 54, 866-876.

Healy, L., \& Fernandes, S. H. A. A. (2011). The role of gestures in the mathematical practices of those who do not see with their eyes. Educational Studies in Mathematics, 77, 157-174.

Köseler, H. (2012). Görme engelliler için fen bilgisi ve matematik eğitimi [Science and mathematics for visually impaired]. Available from http://www.halilkoseler.com

Lincoln, Y. S., \& Guba, E. G. (1985). Naturalistic inquiry. Newbury Park, CA: SAGE.

Ministry of National Education. (2006). Özel eğitim hizmetler yönetmeliği regulation [Education regulations for disabled students]. Ankara, Turkey: Author.

Ministry of National Education. (2013). Ortaokullar için matematik ögretim programı [Middle school mathematics program]. Available from http://ttkb.meb.gov.tr/ 
National Council of Teachers of Mathematics. (2000). Principles and standards for school mathematics. Reston, VA: National Council of Teachers of Mathematics.

Quek, F., \& McNeill, D. (2006). Embodiment awareness, mathematics discourse, and the blind. Annals of the New York Academy of Sciences, 1093, 266-279.

Pritchard, C. K., \& Lamb, J. H. (2012). Teaching geometry to visually impaired student. Mathematics Teacher, 101, 604-608.

Rosenblum, L. P., \& Herzberg, T. (2011). Accuracy and techniques in the preparation of mathematics worksheets for tactile learners. Journal of Visual Impairment \& Blindness, 105, 402-413.

Spindler, R. (2006). Teaching mathematics to a student who is blind. Teaching Mathematics and Its Applications, 25, 120-126.

Varol, Ç. (2010). İlköğretim okullarındaki kaynaştırma uygulamalarının değerlendirilmesi [An evaluation of the inclusive education practices at primary schools]. Ankara, Turkey: Ministry of National Education.

Wang, H. L. (2009). Should all students with special educational needs (SEN) be included in mainstream education provision? A critical analysis. International Education Studies, 2(4), 154-161.

Zhou, L., Parker, A. T., Smith, D. W., \& Griffin-Shirley, N. (2011). Assistive technology for students with visual impairments: Challenges and needs in teachers' preparation programs and practice. Journal of Visual Impairment \& Blindness, 105, 197-210. 